\title{
エル・シッド伝 説
}

\section{1 史 実}

\section{橋 本 一 郎}

通称 El Cid Campeador. Rodrigo Ruiz Diaz仕, 1043 年 Burgos K近rVivar の町でうむれた。国王FernandoI は、晚年領土 を三分割して、Sancho王子KCastilla，Alfonso王子飞Ledn, Garcia王子飞 Galicia を与え, Urraca，Elvira の三王女仙，結 婚しないととを条件として教会領を与えた。1065年王が死如と，シットは SanchoIIのもとて旗手となり，軍の指揮官に任命された。1066 年 Pampl:ona王国と紛争が起り, 両国を代表する騎士の決斗によって解決を図 ったが，その際，代表騎士亿元らばえたシッドは，Pamplona の巨 人騎 士 Jimeno Garcés を破って, El Campeador の称号をえた。領土問 題で対立したSancho, Alfonsoの兄弟は, 1072 年Golpejeraで戦 ら, Alfonsoは破れて, Toledoのモ一ロ王国にし命した。 その後王女 Urraca は, ToledoK酒 Al fonso王子と速絡をとりつつ, Sancho IIK反旗を翻えしたので，SanchoII は大軍を率いて Ur racaの居城Zamo一 $\mathrm{ra}$ をかんんた。その收囲中, 一刺客のために, Sancho Iは暗殺され，Al一 íns O Vが王位をついた。シッドは，León を基盤とする Alfonso Vのも とで，反王党派に属し，Cas t i 11 a貴族を代表する旧勢力の旗頭となった。S a nta Gadea 教会で, Castilla の貴族たちが新しい王に忠誠を暂った時， シッドだけはそれを拒否し，Sancho 王の暗殺は，Alfonsoの命令によるの ではないという数いをさせたため，Alfonso の不興を買ったという伝承があ (Crónica Tudense. 123 6年ごろ成立)。王は, Castilla 貴族の 中心人物たるシッドを懐柔するため，León王の血をひく従妹と結婚させた。

1974年6月19日飞式が挙げられた。シッドの結婚証書によれば,ての結婚 は, Castilla , León両国の費族層の和解を目的としたわのであり,シッド 
はこの結婚によって，王家の一員に列し，発言力がましたてとがわかる。

188 1年 Toledoのモーロ王Alćadir 助けるため, Alfonso II が 転戦している頃、モーロ軍がGorma 2 の城を攻慗略奪した。それを耳にしたシッ ドは, 部下を率いて, Toledoのモ一族をうち, 捕虜 7, 几00人, その他莫 大古战利品をえて, Vivar R底った ( Historia Roderci)。Cの越権行 為は, シッドを羡望する他の有力貴族に中伤の口実を与え，王をてれに耳をかすに レたって，つけと権利の剥奪国外追放の処分をうけた。

妻子を CardenaのSan Pedroの僧院に預けたシッドは, 少数の部下とと すと, Barcelonaの義兄 Berenguerのもとへ身をよせたが，あ主り快く迎 えられなかったため, やむをえず, Zaragoza のモ一ロ王Beni Hud K仕 えるととにした。モー族の王のもとで彼は勇名を馳せ，部下のモーロ人たちは彼 をSidi (殿, Cid) とよんだ。

その頃, 北アフリカを地盤としたイスラム帝国 Almorávido朝の王 Yú suf は, Sevil1 a の Motámid王の援助を口実として，大挙スペインに来襲した。 AlfonsoVI は, Badajoz 付近で, Yúsufと会䯚大敗を契した。乙の思い がけぬ敗战は, 王にシッドと和解与る気を起させた。シッドはての機会を利用して, 協定を結び，以後彼が征服した土地は，シッドとその子孫のものと認める旨を王に 約束させた。Murci a の戦しに遅参したかどで再び王の不興を蒙ったシッドは, Aragón, Barcelona, Zaragaza, Lérida の諸王の連合軍, Al一 fonsoVの軍, および Ý̃ uf のモーロ軍を相手として戦わねばならなくなっ た。これらの勢力の緩衝地帯だったValencia の町に目をつけたシッドは, 三

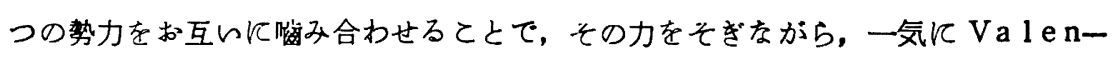
c i a 一向的, 1094 年6月15日, つい反降服させた。Valencia奪回のた めと熟来した Yúsuf の大軍を Cuarte，Bailenの战しで壊堿させたシッ ドは, 無条件降伏した。Valencia の元長官Ben Jehhaf を財宝隐匿の件で 処刑し，ててにVa lencia の財宝と統治権は彼の手に帰した。

それから 5 年 1099 年 7 月 10 日飞死好までの彼の晚年は, アラビア夜話を思 わせる豪華なるのだったらしい。「千一夜物語」に有名なハルン・アル・ラシト゚王 
の寵姫ゾペイダが遺した数々の宝石か凄 J i mena の身を飾り，ペルシアの壁掛け に飾られたシッドの居室には, アラピアの文学, 科学の書が溢れていた。さてシッ ドの死後，Yúsuf の攻势を支えきれななった Jimenaは，Alfonso Vlの

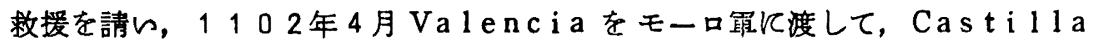
に引きあげた。Cardena の San Pedro僧院に葬られたシッドは, 聖者の列 に加えられた。歴史上のシッドは，戦術の天才であり，有能な政治家であった。彼 の功績は, イスラムの地を侵略するととによって, Reconquis ta 運動の先駆 者となり，国民感情を刺钱した点にある。

\section{2 叙 事 詩}

1140 年頃 成立した"Poema de mio Cid”3700行の詩句をも ち,三部にわかれ、シッドの追放より，モーロ領の征戦、Va lenci a の入城, 娘たちの結婚と, 婿の裹切り, シッドの復䉕と勝利を歌っている。その細部にわた る特徽は, 前と Hispáni ca K掲載したので割爱す万が, との叙事詩にあらわ れたシッド像は萎歴史上の人物の再現とみてよい。"Poema de Mio Cid" の作者は，他の中世民族叙事詩には全くみられない率直さで，モ一王国の侵略者 としてのEl Cid を描いている。Alcócer の町を政篷する時, 部下の将兵 に向って，あまりモーロ人を殺すと略奞品の買ら手がなくなって困るから手加減す るように訓示したシッドはまた, Va l e n c i a の城の天守閣から町を取り巻く Ýnsuf の大軍を見て, 敵軍とは, 大を字を運んでくるお得意棁なのだと妻 Jimena 亿語る現実主義者でるある。娘の恥を雪き, 裹切った Carriónの王 子たちに思知らせるため，Toledo の御前会議に赴的シッドは，まず引出物 を返させたあとで，徐ろに父親としての怒りを爆発させ，王子たちとの決斗を求め る外交家として措かれている。シッド后説を扱った文学作品の中で，すっとも古い ての叙事詩は，その写実的手法で世界の叙事詩中に特異位置を占めているばかり でなく，後世の作品に比して，その人間像の立体性において最もすぐれた作品であ る。"Poema de Mi ○ Cid”として一応の完成をみせたシッドの伝承壮, さまさまな他の伝承と交錯しながら発達した。13世紀に成立した Primera 
Crónica General の中で散文化されたシッド伝説は, "La Refundición del Mio Cid”とよ壮れ，8000行あまりに増大し，のちのロマン セの母胎となった多くの拌話を含んでいる。1344 年に成立した Segunda Crónica General は, "La Segunda Refundición del Mio Ci d”を含む。捜話の增加はあまりないが, シッドの青春時代に関する伝承が胃 られる。この若き日のシッドの姿を文芸化したすので, 叙事詩の最後に位するすの は，14世紀末，または15世紀初頭に成立したとみられる"Re fundi c i ón de las mocedades de Rodrigo”であって, こてにあらわれるシッ ドは、任俚ロマンセに登場する人物に一致し、騎士道小説の主人公に見られるよ な単純て荒々しん性格をすっている。

\title{
3 ロマンセ
}

15 世紀に叙軎詩が衰えると, その断片としてのロマンセが盛んになってくる。 シッドの伝承る，さまさむなロマンセに歌われている。吟洊詩人が職能として成立 しなくなり，長い叙事詩を吟誦するるのがいなくなった時, 叙事詩の中の最る感動 的で詩的な部分だけが，独立した形をとって，民衆に歌われるようになった。てれ が Romance であるが，それは単凉る叙直詩の断片ではなく，全く異質のすのに 転化した。それは叙事詩が，貴族の宴席に興をとえるための，支配階級の芸術たっ たのに対して，ロマンセは，民衆の中から生れた，民衆のための尝術だったからで ある。すでに末期の叙事詩にみえる荒々しいRodrigo というイメーシは、ロマ ンセの中で一層明瞭にあらわれてくる。年老らた父がLo \& a n o 伯からうけた恥辱 を, 父に代って雪どうとしたシッドの心に浮んだのは, 恋人 Jimena の姿ではな no

\author{
Pensativo estaba e l Cid \\ Viéndose de pocos años \\ para vengar a su padre \\ matando al conde Lozano; \\ miraba el bando temido
}


del poderoso contrario

que tenía en las montañas

mil amigos asturianos;

シッドは，敵が有するアストリア地方の兵力を考えて，しばしためらっているの である。父を殺された JimenaがFernando王に、シッドの処罰を願った時, 彼は自分が手にかけた男の娘を見てる別に惻陰の心を起した模様はない。Jimena の悲痛な叫び声に背を向けて, 平然と馬にのって去って行く。 Jimena が何度も 王に裁さと復蚝とを求めるのは、シッドの傍若無人な振舞いが目に余ったからであ る。

Con mancilla vivo, rey,
con ella vivemi madre;
cada dia que amanece
veo quien mato mi padre
caballero en un caballo
yen su mano un gavilan;
por hacer me más enojo
cébalo en mi palomar;
con sangre de mis palomas
ensangrentómi brial.

Jimena の訴えを聞いた王は, Rodrigo と父の Diego Lainez, その 他 Vivar の騎士たちを召喚するが，王の面前でも Rodrigo の傲慢不抙な面 構えは少し変らない。彼は王の怒りにふれて, 追い払われる。しかし名君 Fer一 nandoは, Rodrigo の反骨精神が却って気に入り, つ次 Jimena と彼と を妻わす気になる。

式に臨んだシッドは，Jimena を抱をながら，流石に弁解のととばをロでする。 Maté a tu padre, Jimena. pero no a desaguisado, matéle de hombre a hombre 
para vengar un agravio.

しかし,シッドは瀻細な女心を理解しない荒武者だった。弁解の辞をのべたロの 下からもう次のような恩着せがましいせりふを吐いてしまう。
Maté hombre y hombre doy,
aquí estoy a tu mandado;
en lugar del muerto padre
cobraste marido honrado.

こうした考え方は, 必ずしもシッドの教養の低さをあらわすものではないので, 当時の通念として，父を殺したものは，その娘と結婚する義務，つまり娘を扶荃す る義務があった。「数日前彼は (シッド) ゴルマス伯ゴメスと決斗して破り, 死に 至らしめた。乙の事件の結果, 彼は伯の娘で相続人のト゚ニャ・ヒメーナと結婚した。 ヒメーナ自身が王に, 彼の資性に強くひかれているので夫として与えてくれるか, あるいは，彼女の父を殺した罪により法に従って彼を罰するかして下さいと願った。 結婚式がとり行なわれ，すへてての人を喜ばせた。彼は父の財産に加えて妻の財産を 所有したので, 権勢と富とが增大した。」( His toria d'Espana. Lib. X. Cap. V. Mari ana)

Ma r i a na のスペイン史は，考証的ではなく，伝承の集成である。シッドの史 実の項で書いたように，Rodrigo と Jimena の結婚は，政略的なおのであり， しかもAlfonsoll の治下であって, Fernando 主と壮関係がいし, Rodrig。がJimenaの父を殺した事実はない。"Las mocedades del Cid”と“Le C id”の素材となったシッドの恋の悲劇は, 後期の叙憘詩と ロマンセがうんだ物語なのである。

Fernando王の死後，Sancho】のるとで指揮官となったシッドは，Zaー mora の攻囲で，王の暗殺に会い，新しい王 Alfonso に無実の哑いをさせた ことで，祖国を追放される。ここでロマンセの作者は、シッド追放の原因を王の怒 りに㷌している。“Crón i c a Rimada”その他の末期の叙喜詩怰, 廷臣たち のシット゚への羡望が原因だとのべているから，ての点でもロマンセのもつ歷史解釈 は著しく抒情への傾斜をすつといえるであろう。抒情への傾斜の点で有名なのは， 
Zamora 城に攻囲された王女 Ur raca が城壁の上に姿を見せ，城壁の下にたた ずむシッドに向って，その不忠をなじる場面を歌った "Afuera, afuera， Rodrigo"のロマンセである。

i Afuera, a fuera, Rodrigo,

el soberbio castillano!

Acordásete debría

de aquel buen tiempo pasado

que te armaron caballero

en el a l tar de Santiago,

cuando el rey fué tu padrino,

tú, Rodrigo, el ahijado;

mi padre te dió las armas,

mi madre te dió el caballo,

yo. te calcé espuela de oro

porque fueses más honrado,

pensando casar contigo,

i no lo quiso mi pecado!

casástete con Jimena,

hija del conde Lozano;

con ella hubiste dineros,

conmigo hubieras estados;

dejaste hija de rey

por tomar la de un vasallo.

Urraca 姫は，兄 Sa nchoの横死飞際しても淚一つ見せす，弟Garc i a を城に幽閉病死させた気丈な女性で，年代記作者から“Dona de a Ima crue 1 ”と綽名されている仼どだが，乙のロマンセでは，幼馿染みシット゚への恋 に脳む女として描かれ，聴くめのの耳には，饸すJimenaのライバルですあるか の上うな感を与える。そしてUrraca 姖とシッドと Jimena との恋の葛藤上 
とレうテーマは, Castuo の制にうけつがれ, さらにCorne i 11 eの制の重要 なテーマに成長して行った。

追放侵のシッドの事跡は, Va le nci a の征服, 娘たちの結嫖, 婿の裹切り, Toledo の御前会議, シッドの晚年の生活去と，叙重詩との違いはあまりない。 ただ"Poema de Mio Cid”の中で立体化されていたシッド像がしでく りふれた英雄像に変しているだけである。

\section{Las mocedades del Cid}

Guillén de Castro y Bellvis( $1569 \sim 1631$ ) は 1618 年に“Las mocedades del Cid"を書的。のちに"Las hazañs de I Cid”。書いているか, 彼の名を不朽にしたのは, “Las mocedades del Cid”であり,とくKCorneille の“Le Cid”の紛本となった 第一部である。

第一部は，青年シッドの騎士叙任式に始まる。Rodri go の晴れの門出を祝う ために，王は自ら彼に武器を与え，王妃は馬を与えた。Urraca姫の美しい手が 若い騎士の足に金の拍車をつける。息子の晴れ姿を見守るうれしげな老将 Di e g o La ínez と，そのライバ Loçano伯の苛立たしい視線。乙の場面は，国家の 柱石である二人の重臣の間にある暗斗を暗示し, つを゙の喧茟場の伏線である。

式の後，王は重臣を集めて，王子 Sanchoの師伝としてDi e go Laínez を任命する。それが Locano伯を怒らせ，Laínezの老令を嘲り，若壬子の 教育者としては，現役の将軍たる自分て艺適任者だと主張する。王の制止るすかす 言い募った伯は，怒りに市かせて Laíne z飞平手打古をくわせる。

この争いの原因につレて，古来の伝承は，狩編の際の争いだとしている。狩りの 獾物を奪われたため( Crónica Rimada), 或は, 狩りの際, 鬼をとり逃か したのを伯が嘲笑したため（Romancero），と伀承されている。Sancho王 子の師伝問題は，Castro の創意である。

恥にふえながら家に戻った La íne zは，伝家の宝刀を取ろうとするが，年老い た彼の腕はその重みに堪えない。三人の息子の勇気をためした後，父は Rodrigo 


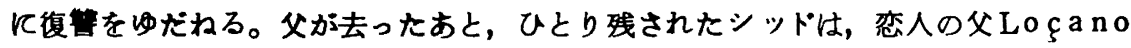
伯を殺さなければならない自己の缩命に悩む。第 1 幕最後の場は，王官前の広場で ある。王女と Jimena が空から姿を見せ，舞台の反対側から父が励ます中て， Rodrigo はみどと父の仇をうつ。第 2 幕。父の血に染んだ布を持ったJimena と，伯の血で煩を染めた La i ne z とが王の滕にとりすがって懇願する。Ro一 drigo へのはげ恋を抑えて, 恋人の処刑を求める Jimena の苦悩は Cas t ro の㓺以後のテーマである。留守中 J i me na の部屋にしのんだシッドは，帰って来 たJimenaの言葉から，その心が変っていないてとを確める。事件後，家を出て らた Rodrigoは，父からモーロ族来謷の報を聞き，戦場へ赴く。

Urraca 姫の居城。庭にひとり佇んでRodrigoを佃ぶ姫の前を，一隊の兵 を率いたシッドが通りすをる。彼は，姫から心の籠った祝福をうける。戦場の場面 モーロ軍との乱戦の模样をロネに語る羊飼たち。舞台は一転して王官の一室。San一 cho 王子の剣衔の矰古のあよ，モーロ王の捕虜をつれたシッドが凱旋する。とそ てへ長い表服に包生れた J i me na がかけつけてさきの訴えをくりかえす。第 3 萛。 Urraca と Sancho との不仲を王が丕えているとてろへJimenaが再び訴え 飞来る。王壮彼女の心をためそうとして，Rocir i go 戦死の虚報を伝えさせる。 Jimena 洨気絶しそうになるが，おく生て敵の死を聞いた喜びのためだと言いは り，その首を持参したるのには，財産はるとより自分の体す賭けると公言する。 Compostela 寺院に向うシッドの一行は，沼地で哀れな䝿病の乞令を助け， 食事をとるにし衣服を与える。实然乞食の姿は消え，スペインの守詜神聖ラサロの 姿を現わして，シッドの慈を賛え，来るべを栄光の未来を予言する。

Calahorraの町をめぐって, Aragon, Castil1 a 両国は係争を続けて いたが，見るも恐ろしい巨人で, Aragónの大使 Martín Gonzales は, シッドとの一騎打ちによって事を决しようと提案し， あわせて，美しい Jimena をすわがものにしようと企む。挑戦をうけて立つシッド。恋人の危険を思い，巨人 の磨手に怯える Jimenaのもとに, シッドの首を持った騎士が彼女を探している という報らせが届く。今は, 遠㦄気兼ねる忘れて淚にくれる娘の前に現われたのは， Rodrigo 自身であった。彼は，自分の首を自ら持参したのである。Loçano 
伯の横死以来一年あまりで，二人はめでたく結ばれることになる。

第二部三慕は, $Z$ amor a 城の攻团, SanchoII の暗殺, Alfonso VI の即 位，などを内容とし，興味の中心忙 Zamora の姫君としてのUrraca と城を死 守する騎士たち，姫に同情しつつる，Sancho【に従わねばならないシッドの苦 支にある。ToledoK亡命したAlfonso王子と，美しいモー只姫君 Zay一 $\mathrm{da}$ との恋が劇飞色彩をとえている。第2 部は, Zamoraの戦的をテーとした ため，場面の転換がはげしく，剣㓺としての性格が強く，第1部にみられるような 心理描写に乏しい。

Castroは，民衆に親しまれているロマンセに忠実な史㓺をつくるてとで，史 実の生生のシッド像でなく，大衆のるっていたイメージにふさわしレシッド像の 造型飞成功した。

\section{Le $\mathrm{C}$ id}

CastroのEl Cid は, 前述のように，すでに人々の心にイメーシとして定 着している伝承上のシッド像に忠実である。しかし，彼は，以前の伝承てはなかっ た要素，つ主り父の恥を雪ぐために恋人の父を殺さなければならないという悩み， 恋と義務との板挾みというテーマを導入した。彼の劇の成功は，このテーマが大衆 の赀好飞投じたためである。ただ Cast r o の悩みは，伝承によって定着されたシ ッド像と，彼が創造した「恋に悩む貴公子」シッドとをいかに掘合させるかにあっ た。との二つのイメージの矛盾は，例えば 3 幕第 5 場の J i mena 訴願の科白にあ らわれている。1973行〜 1977 行にかけて, 前に引用した" $\mathrm{Cada} \mathrm{dia}$ que amanece…." 反始末るロマンセが殆んどその生利用されているが，乙 れらの詩句は，ロマンセの主人公としての荒武者シッドにはふさわしくても，Ca stro の描いたイメージとは相容れない。こうした矛盾を感しで,てれを克腿し， シッドのもつ歴史性を搭てて, 恋に悩み斿からすそれにうち勝つ意志の人として描 レたのが, Corneilleである。Corneilleは，3慕69场をるつCast r o の Comedia t 5 幕 32 場飞改編し, 3004 行の詩句を 1840 行に削 り, 登場人物二十数名を 12 名にし, 騎士叙任式, 聖ラサロの出現, モーロ人との 
戦いの場面などを省略している。

形式の単純化は，劇のダイナミックな面白味を失わせたが，静的な梁みをすつ心 理劇飞刑華させた。単純化して成功した例をあげよう。La i nezが息子たちの勇 気をためす場面は多分に喜很風である。La i nezは弟息子の指を折れる任ど握り

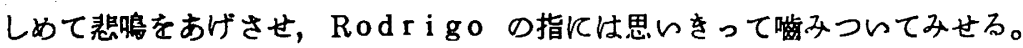

Muérdele un dedo de la mano Don Diegue fuertemente

Rodrigo. I Padrel !Soltad en Rodrigue, as-tu du coeur? mal hora!

I Soltad padre, en Don Rodrigue hora mala! iSi no fuerades mi padre Tout autre que diéraos una bofetada!... monpére

Diego L. Ya no fuera la primera. L'éprouveratt sur l'heure. Rodrigo. ¿ Cómo ?

Diego L. I Hi jo, hi jo del a lma! $\begin{array}{ll}\text { iEsse sentimiento adoro, leur bien doux! } & \end{array}$ essa collera me agrada, essa braveza bemdigo!

Castro

( 468 行 $\sim 477$ 行)
Don Diegue

agreable colere!

Corneille ( 261 行 263 行)

Castroが延々 50 行费して描らた場面をCorneille はわずか 3 行で 強く再現している。しかし，峃純化はつね成功するとは限らない。Conde Lo-canoと Diégo La ínez が王と重臣2人の前で言い争う場面では, Castro 刻の方がはるかに力強的。伯は, 自分とそ王子の師妘にふさわしいと主張す る。

\section{Le Com te}

Conde. IYo lo merezco. . . . !

Rey.

¡Vasallós!

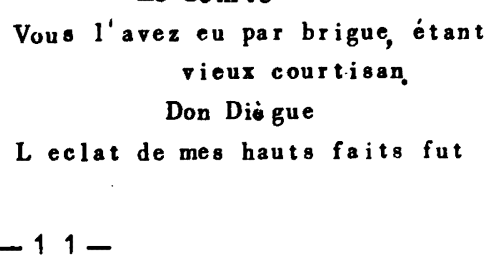




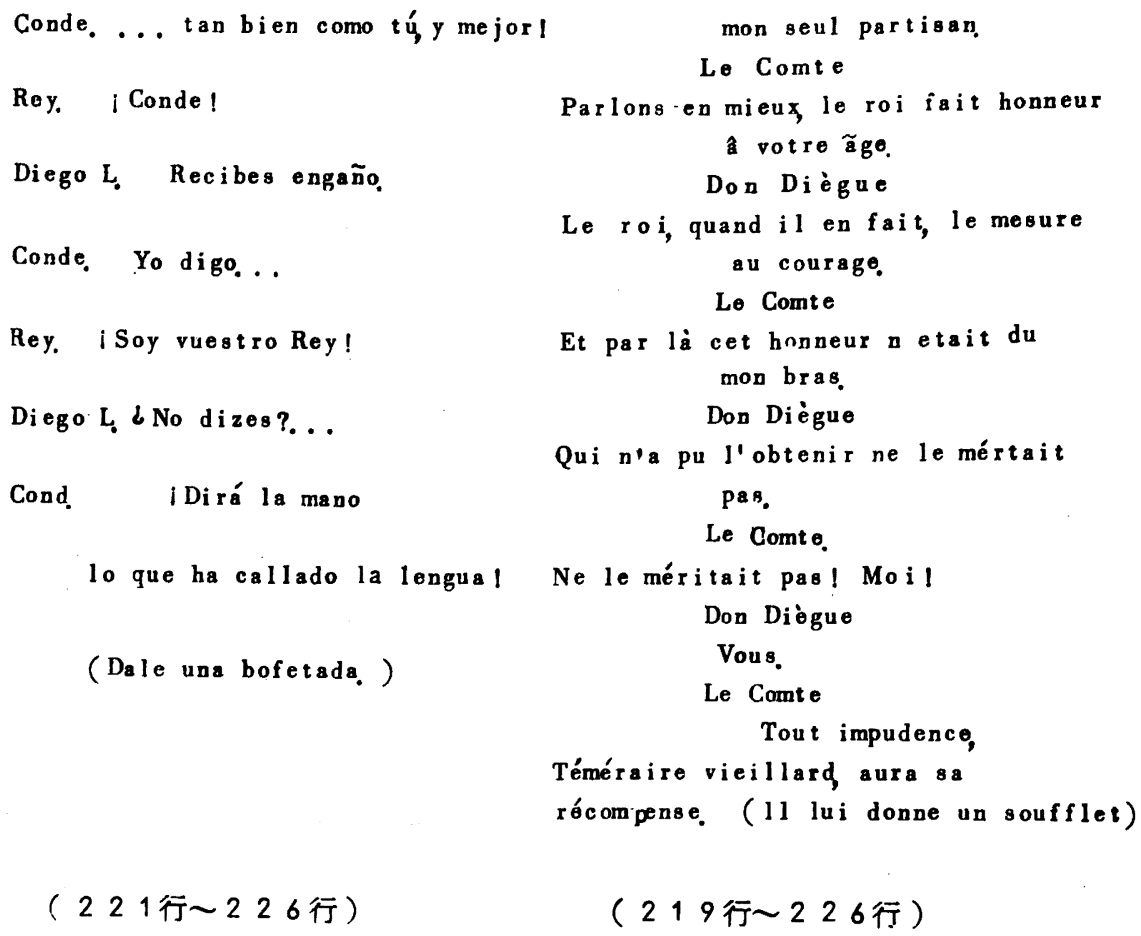

Corneille の詩句は, ふつう白刃のひらめをを思わせると言われてていら個所 であるが，2人の武将の葛藤は，王と同僚上いう他人の目を意識するととによって 白熱化する。王の科白が 2 人を制止しょうとしつつ却って，争いに油を注ぐ結果に

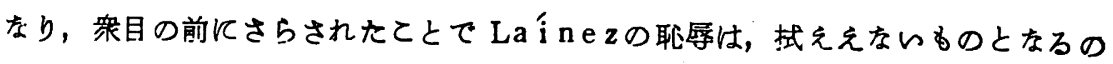
だ。

"Le Cid" K对する"Las mocedades del Cid"の影置は, 比較 文学の好個の題材であるため，昔から業績が多いが，大別するとフランス側からみ たすのと，スベイン側からみたすのとにわけられる。日本で発表された論义の代表 的なすのとして，太蚝施門氏の「フランス古典悲湢の形成」(甲鳥畫院, 昭和 17 年）功引用させていただくことにする。「とれは（Las mocedades del $\mathrm{C} i \mathrm{~d}$ ) 当時流行の悲喜很であるという以上にあまり特別の興味染ない。捧られた 
頪を血の色で染めて老武士は家に熳って行く。そうした見物の感觉に阿ねる部分 も

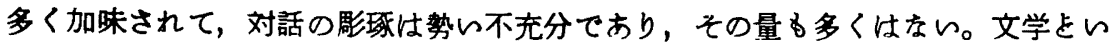

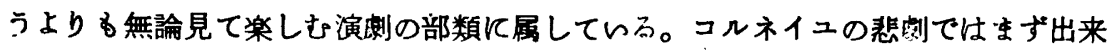
るだけ外部事件を少くし，（中略）芝居のゆでの時間の経過はやっと一日半足らず の短かさに縮めてある。自然，諸人物の互いに交わす対話が中心の，殆んど全部の

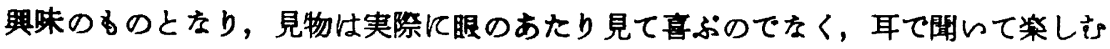
ようと作られている。聞的感し珜断して悦ぶ, 文学的友作に一躡フランスの『エ

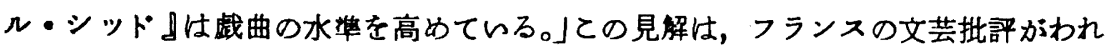
われに教えているすのの公約数を示す。てして主たいわゅる世界文学史の本すたら ていはてれに近い意見をのへている。あいてくスペイン側の発言は声がさい上う

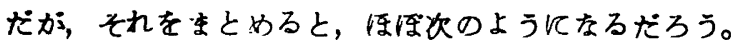

「スベイン文学の特性は, 强ら伝統主義にある。そのあらわれは，中世の英雄詩 がロマンセの形で今る向生きているてとである。Castroの作品壮，国民的英雄 の若き日たを，ロマンセの忠実な劇化という手法を用いて，再現したすのである。 ての制は "Poema de Mio Cid” の持つ素朴てたく生しレシット像を中核 として， ロマンセの色彩と香気を加味したるのでる。それに反して, Conne.i 1$1 \mathrm{e}$ は，三一致の法則によって，霊感をわれ，原作のもつ生彩にとんだ面白さ

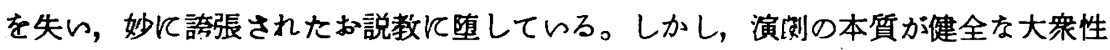

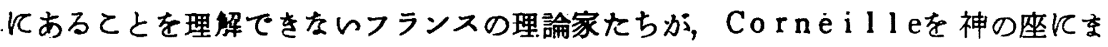
つりあげ，Castroの姿は消えてしまった。Castroが再び脚光を浴びたのは

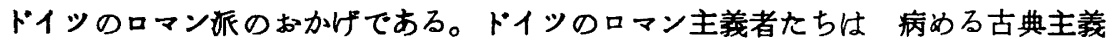
の拘束をうち破って，健康息吹きを文学入導入したが，ての時彼らの眼㣗クロー ズップされたのは，民族の体臭を漂わせているロマンセであり，それを基盤とし た Comediaであった。」

ての相反する二つの見解は，多かれ少かれどの批訐家の中にあ認められるか，わ れわれが客観的に謊むかきり，二つの意見は，いずれす事物の一面を見ているすの

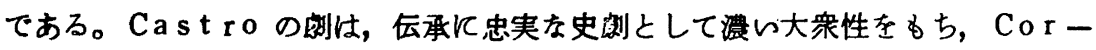
ne I le の汶は, 心理の堀り下げの深さによって, Rac i ne の悲劇を草備した。 
2 人はままた相異なる環境のもとにいた。Cas t roは自由で奔放な黄金世紀の自由 则の㓱始者 Lope de Vega の影繁のもとにあり, Carneilleは絶対王制 下の, 中央集権体制, Descartes の哲学が支配し, アリストテレスの「詩学」 を金科玉条とするような空気の中に生をていた。Ca s t ro の前にある客観は，お 生り行儀のよくない平土間の大衆だったが, Corneilleが対衂としたのは，モ ラリストの文学をはぐくんだ上流サロンの常連だった。根本的には, この環境の差 か，内容と詩句において，類似しながら，イメーシにおいて相隔った 2 人のシッド をうんでのである。

“Le Cid”は, 第1幕第 1 場で, Chimene の恋, 同じく第 2 場で王女 （Urraqu）の恋を語って，㓢の主軸か恋の葛藤にあるととを示している。 Corneillekとって, シッドは，国民的英雄ではない。たまたま眼にふれた Castroの脚本が彼の理想像にあては生っただけである。Corneilleは，シ ッドのReconquis ta の英雄としてではなく，恋悩みながらす，騎士の体面 をより重んじる意志の人として造型した。彼の功績は，それ以前の悲测が，運命の 力の前に無力だった主人公しか作り得なかったのに対し，自己の意志によって生き る個性的な人物を創造した点にある。彼柱 Ca s t r o のすつロマンチスムを利用し て，新しい悲㓺の樹立に成功したが，観客の心を誘ったそのロマンチズム自体が， はからする，殷壇の收梁の生ととなり，有名な「ル・シッド論争」が起った。その 数年間にわたるCorneill の沈黙は, 彼の方向をComediaから遠さけ, 古 典主義へと向わせるすのであった。1648 年版の序文で, Chimene が父の敵 と結婚した行為について，おずおずとして絶对視されたのは，イタリアへの㷌低か させる業である。それに反して，Hardyから Racineに至る作家たちは，スペ インの名作の多くを模倣したか，どて主でも素材として取扱った。その受容は，筋

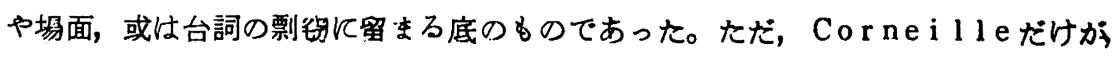
Castro の原作を忠実に翻案したが,しかしE1 Cid汢所詮スーインの歷史的境と 風土をるつ人物であって, Don Juan のような国際性を身につけていなかった ので, Le Cid に化した時, その英雄的風格を失ら，恋之義務の相兛に悩む貴公 子飞変身した。Corneille 以後の文学は，いずれる風雅を愛する贵公子とし 
てシッドを描いている。世紀末の詩人 Georges Fourest は，その“La Negresse blonde” の中で, Chimene のロを籍りて, てうしたシッド 文学の動向を要約している。

"Dieu! qu'il est joli garçon l'assassin de Papal (了) 